\title{
PERBEDAAN KADAR SENG (ZN) RAMBUT BERDASARKAN DERAJAT STUNTING PADA ANAK USIA 6-9 TAHUN
}

\author{
Arindha Rahmawati, Yekti Wirawanni ${ }^{*}$ \\ Program Studi Ilmu Gizi Fakultas Kedokteran Universitas Diponegoro \\ Jl.Dr.Sutomo No.14, Semarang, Telp (024) 8453708, Email : gizifk@undip.ac.id
}

\begin{abstract}
Background: Stunting is a linear growth disorders are caused by chronic malnutrition especially zinc deficiency. Hair zinc concentrations can describe zinc status in the long term. The aim of this study is to investigate difference hair zinc concentrations based on degree of stunting in 6-9 years old children.

Method: This cross sectional study was carried out on 57 school children aged 6-9 years. The subjects were chosen by stratified random sampling. Assessment degree of stunting are expressed by Height for Age Z-score (HAZ). Hair zinc concentrations was measured by Atomic Absorption Spectrophotometry (AAS) methods, the hair zinc concentrations less than 70 ppm was considered as chronic zinc deficiency. Bivariate analysis was using Kruskal Wallis, Mann-Whitney and Rank Spearman.

Results: The prevalence of nonstunting $(-1 \leq H A Z<2 S D)$, mild stunting $(-2 \leq H A Z<-1 S D)$, moderate stunting ($3 \leq H A Z<-2 S D)$, and severe stunting (HAZ<-3SD) was 38,6\%,33,3\%, 22,8\%, and 5,3\%, respectively. The median value hair zinc concentrations were 579,13 ppm. Out of 57 subjects, 26,3\% had normal hair zinc concentrations, 73,7\% had excess hair zinc concentrations, and no subject that experience of zinc deficiency. There is a significant difference on hair zinc concentrations based on degree of stunting $(p=0,010)$ and positive correlation between hair zinc concentrations with Height for Age Z-score (HAZ) ( $r=0,303 ; p=0,022)$.

Conclusion : There is a significant difference between hair zinc concentrations based on degree of stunting and significant correlation between hair zinc concentrations with Height for Age Z-score (HAZ). Hair zinc concentrations increased with increasing Height for Age Z-score (HAZ).
\end{abstract}

Keywords : Degree of stunting; Height for Age Z-score (HAZ); Hair zinc concentrations; malnutrition; children

\begin{abstract}
ABSTRAK
Latar Belakang : Stunting merupakan gangguan pertumbuhan linier yang timbul akibat malnutrisi kronis salah satunya defisiensi seng. Kadar seng rambut dapat menggambarkan status seng dalam jangka lama. Tujuan penelitian ini adalah untuk mengetahui perbedaan kadar seng rambut berdasarkan derajat stunting pada anak usia 6-9 tahun.

Metode : Studi cross sectional dengan jumlah subjek 57 anak sekolah yang berusia 6-9 tahun dipilih dengan cara stratified random sampling. Penilaian derajat stunting dinyatakan dengan z-score tinggi badan menurut umur (TB/U). Kadar seng rambut diukur dengan metode Atomic Absorption Spectrophotometry (AAS), kadar seng rambut $<70$ ppm dinyatakan defisiensi seng kronik. Analisis bivariat menggunakan Kruskal Wallis, Mann-Whitney dan Rank Spearman.

Hasil : Prevalensi nonstunting $(-1 \leq Z$-score $T B / U<2 S D)$, mild stunting $(-2 \leq Z$-score $T B / U<-1$ SD), moderate stunting (TB/U -3 $\leq Z$-score $T B / U<-2 S D)$, dan severe stunting (TB/U <-3SD) berturut-turut yaitu 38,6\%, 33,3\%, 22,8\%, dan 5,3\%. Nilai median kadar seng rambut yaitu 579,13 ppm. Dari 57 subyek, 26,3\% tergolong kadar seng rambut normal, 73,7\% tergolong kadar seng rambut diatas normal, dan tidak terdapat subyek yang mengalami defisiensi seng. Terdapat perbedaan yang bermakna pada kadar seng rambut berdasarkan derajat stunting $(p=0,010)$ dan korelasi positif antara kadar seng rambut dengan $z$-score $T B / U(r=0,303 ; p=0,022)$.

Kesimpulan : Terdapat perbedaan antara kadar seng rambut berdasarkan derajat stunting dan terdapat korelasi positif antara kadar seng rambut dengan z-score TB/U. Kadar seng rambut meningkat dengan meningkatnya zscore $T B / U$.
\end{abstract}

Kata Kunci : derajat stunting; z-score TB/U; seng rambut; malnutrisi; anak

\section{PENDAHULUAN}

Stunting

pertumbuhan linier yang disebabkan karena malnutrisi kronis, dimana tinggi badan berada di bawah tinggi badan normal, yang dinyatakan dengan z-score tinggi badan menurut usia (TB/U) berdasarkan usia dan jenis kelamin yang ditetapkan oleh World Health Organization (WHO). Stunting pada anak sekolah merupakan manifestasi dari stunting pada masa balita, karena tidak ada

${ }^{*}$ Penulis Penanggungjawab 
perbaikan tumbuh kejar (catch up growth), asupan zat gizi makro dan mikro tidak sesuai dengan kebutuhan dalam jangka lama, dan penyakit infeksi. Laju pertumbuhan (growh spurt) baik lakilaki maupun perempuan melambat antara usia 6-9 tahun. Growth spurt meningkat pada masa bayi dan pubertas. Laju pertumbuhan anak baik lakilaki maupun perempuan hampir sama cepatnya sampai usia 9 tahun sebelum memasuki pubertas. ${ }^{1,2}$

Prevalensi moderate stunting pada anak usia 6-12 tahun secara nasional berdasarkan Riskesdas 2010 sebesar 35,6\%. Prevalensi severe stunting pada anak usia sekolah di Jawa Tengah yaitu sebesar 14,9\% dan moderate stunting sebesar 19,2\%. Hal ini menunjukkan bahwa lebih dari sepertiga $(34,1 \%)$ anak usia sekolah dasar di Jawa Tengah tergolong stunting ketika memasuki usia sekolah. ${ }^{3}$

Seng (Zn) adalah trace element essensial yang berperan dalam sintesis, sekresi, dan aksi hormon pertumbuhan (Growth Hormone). Rendahnya sistem regulasi hormon pertumbuhan dapat menghambat pertumbuhan linier. Defisiensi seng dihubungkan dengan terlambatnya pertumbuhan, rambut rontok (alopecia), dan menurunnya fungsi imun. Konsumsi sumber seng pada anak sekolah di negara berkembang masih tergolong rendah, dapat dilihat dari rendahnya konsumsi sumber pangan hewani dan tingginya konsumsi sumber fitat yang terdapat pada pangan nabati, dimana fitat diketahui dapat menghambat absorbsi seng. Pangan hewani adalah sumber seng yang paling baik, karena bioavailabilitasnya lebih tinggi daripada sumber seng dari pangan nabati. Rendahnya asupan seng dapat memicu terjadinya defisiensi seng. ${ }^{4,5}$

Stunting pada anak-anak dikaitkan dengan kekurangan zat gizi mikro baik tunggal maupun ganda, seperti defisiensi seng. Penelitian di Iran menunjukkan bahwa defisiensi seng secara signifikan lebih tinggi pada anak sekolah yang stunting daripada nonstunting. ${ }^{5}$ Penelitian di Indonesia menunjukkan bahwa kondisi stunting lebih dipicu oleh keadaan seng dalam tubuh daripada faktor kadar serum retinol. ${ }^{6}$ Penelitian di Ghana menunjukkan bahwa tidak ada hubungan antara stunting dengan kadar seng rambut. ${ }^{7}$

Kadar seng rambut merupakan biomarker untuk mengetahui status seng tubuh, dimana seng rambut akan diambil sebagai seng endogen untuk mencukupi kebutuhan seng. Analisis kadar seng rambut lebih tepat menggambarkan status seng pada masa lampau, sementara stunting merupakan kondisi malnutrisi yang sudah berlangsung dalam jangka lama (chronic malnutrition). Kadar seng serum tidak selalu menggambarkan secara tepat kadar seng dalam tubuh karena seng berikatan dengan albumin, sehingga akan berubah bila kadar albumin berubah ${ }^{8,9}$

Berdasarkan hasil penjaringan anak sekolah tahun 2011 di SDN 1 Purwokerto Kecamatan Patebon Kabupaten Kendal terdapat 12 siswa $(33,3 \%)$ dari 36 siswa kelas 1 tergolong stunting. ${ }^{10}$ Oleh karena itu, melihat kondisi tersebut peneliti mencoba untuk meneliti perbedaan kadar seng rambut berdasarkan derajat stunting pada anak usia 6-9 tahun di Sekolah Dasar Negeri (SDN) 1 Purwokerto Kecamatan Patebon Kabupaten Kendal.

\section{METODE PENELITIAN}

Penelitian ini termasuk dalam ruang lingkup keilmuan gizi masyarakat yang dilakukan di SDN 1 Purwokerto Kecamatan Patebon Kabupaten Kendal pada bulan April 2012. Jenis penelitian ini adalah penelitian deskriptif analitik dengan pendekatan cross sectional.

Populasi target penelitian ini adalah anak sekolah dasar usia 6-9 tahun, sedangkan populasi terjangkau adalah siswa-siswi yang berusia 6-9 tahun SDN 1 Purwokerto Kecamatan Patebon Kabupaten Kendal. Besar sampel yang digunakan sebanyak 57 siswa yang dipilih dengan cara stratified random sampling berdasarkan usia yaitu 6-9 tahun. Subyek yang dipilih telah memenuhi kriteria inklusi yaitu berusia 6-9 tahun, bersedia mengisi informed consent, tidak sedang menderita penyakit infeksi saat penelitian, tidak menderita kelainan bawaan saat lahir, dan tidak mengecat rambut.

Variabel terikat penelitian ini yaitu kadar seng rambut, variabel bebas yaitu derajat stunting. Data primer yang dikumpulkan meliputi identitas sampel, pengukuran antropometri tinggi badan dan berat badan, serta pemeriksaan kadar seng rambut. Pengukuran antropometri tinggi badan menggunakan microtoise dengan ketelitian $0,1 \mathrm{~cm}$ dan berat badan menggunakan timbangan injak digital dengan ketelitian $0,1 \mathrm{~kg}$, bersamaan dengan itu dilakukan pengambilan sampel rambut untuk dilihat kadar seng rambut.

Pengukuran kadar seng rambut dilakukan melalui 2 tahap yaitu proses destruksi basah dan pembacaan Atomic Absorption Spectrophotometer (AAS) yang dilakukan 3 kali. Pengambilan sampel rambut yaitu sampel rambut dipotong $4-5 \mathrm{~cm}$ dari kulit kepala atau jika rambut kurang dari $4 \mathrm{~cm}$ maka diambil dari ujung sampai pangkal rambut. 
Rambut diambil secara acak di daerah occipital kepala menggunakan gunting stainless steel. Sampel rambut yang diambil kira-kira 50-80 mg dan disimpan di plastik polyethelene. Sampel rambut yang telah terkumpul dikeringkan dan dicuci dengan air kemudian dimasukkan ke dalam elemeyer dan ditambahkan $10 \mathrm{~mL}$ aquaregia yang terdiri dari $\mathrm{HCl}$ (chloric acid) dan $\mathrm{HNO}_{3}$ (nitric acid) pekat dengan perbandingan 3:1. Sampel rambut tersebut didiamkan 1 malam, kemudian dipanaskan sampai mendidih menggunakan hotplane sampai sampel rambut tercampur, kemudian didinginkan. Sampel rambut yang sudah tercampur menjadi larutan tersebut diencerkan menggunakan aquadest sampai volume $25 \mathrm{~mL}$. Larutan tersebut merupakan larutan hasil destruksi sampel rambut untuk dianalisis dengan pembacaan AAS. ${ }^{11}$ Hasil pembacaan AAS kadar seng rambut dinyatakan dalam parts per million ( $\mathrm{ppm}$ ).

Derajat stunting dinyatakan dalam z-score TB/U, dihitung menggunakan software WHO Anthroplus yang merupakan aplikasi dari WHO Reference 2007 pada usia 5-19 tahun. Hasil pengukuran $\mathrm{z}$-score $\mathrm{TB} / \mathrm{U}$ diklasifikasikan menjadi derajat stunting. Klasifikasi derajat stunting menurut WHO new Growth Standards dinyatakan menjadi 4 yaitu nonstunting $(-1 \leq \mathrm{Z}$-score $\mathrm{TB} / \mathrm{U}<2$ $\mathrm{SD})$, mild stunting $(-2 \leq \mathrm{Z}$-score $\mathrm{TB} / \mathrm{U}<-1 \quad \mathrm{SD})$, moderate stunting $(-3 \leq \mathrm{Z}$-score $\mathrm{TB} / \mathrm{U}<-2 \mathrm{SD})$, dan severe stunting $(\mathrm{TB} / \mathrm{U}<-3 \mathrm{SD}) .{ }^{12}$ Hasil pengukuran kadar seng rambut dikategorikan berdasarkan cut off point kadar seng rambut yaitu defisiensi seng kronik (<70 ppm), defisiensi seng ringan (70-100 ppm), kadar seng rambut normal (>100-500 ppm), kadar seng rambut diatas normal (>500 ppm).

Pengolahan dan analisis data menggunakan program Statistical Package for Social Science (SPSS) ver. 16 for Windows. Analisis data meliputi analisis univariat dan bivariat. Data yang berskala numerik seperti umur, z-score tinggi badan menurut umur $(\mathrm{TB} / \mathrm{U})$, dan kadar seng rambut dideskripsikan sebagai nilai minimum, maksimum, median, rerata dan standar deviasi. Data yang berskala kategorik seperti jenis kelamin, derajat stunting, kategori kadar seng rambut dideskripsikan sebagai distribusi frekuensi dan persen. Analisis bivariat menggunakan uji Kruskal Wallis untuk uji beda kadar seng rambut berdasarkan derajat stunting, Mann-Whitney untuk uji lanjut Post Hoc dan Rank Spearman untuk uji korelasi dimana $p$-value $<0,05$ dikatakan bermakna.

\section{HASIL PENELITIAN \\ Karakteristik subyek penelitian}

Penelitian ini melibatkan 57 anak sekolah dasar usia 6-9 tahun sebagai subyek penelitian. Karakteristik subyek penelitian dapat dilihat pada tabel 1.

Tabel 1. Karakteristik subyek penelitian $(\mathrm{n}=57)$

\begin{tabular}{lcc}
\hline \multicolumn{1}{c}{ Karakteristik } & $\mathbf{n}$ & $\mathbf{\%}$ \\
Jenis Kelamin & & \\
$\quad$ Laki-laki & 28 & 49,1 \\
$\quad$ Perempuan & 29 & 50,9 \\
Usia & 9 & 15,8 \\
6 tahun & 17 & 29,8 \\
7 tahun & 19 & 33,3 \\
8 tahun & 12 & 21,1 \\
9 tahun & & \\
\hline
\end{tabular}

Rerata usia subyek penelitian adalah $8,06 \pm 0,93$ tahun, dengan umur termuda 6,33 tahun dan tertua 9,83 tahun.

\section{Derajat Stunting}

Rerata z-score TB/U subyek penelitian yaitu $-1,36 \pm 0,92 \mathrm{SD}$. Perempuan memiliki z-score
TB/U (-1,58 $\pm 0,79$ SD) lebih rendah daripada lakilaki $(-1,13 \pm 0,99)$. Z-score TB/U kemudian dikategorikan berdasarkan derajat stunting. Prevalensi derajat stunting subyek penelitian dapat dilihat pada tabel 2 .

Tabel 2. Prevalensi derajat stunting anak usia 6-9 tahun

\begin{tabular}{|c|c|c|c|c|c|c|}
\hline & \multicolumn{2}{|c|}{$\begin{array}{c}\text { Laki-laki } \\
(n=28)\end{array}$} & \multicolumn{2}{|c|}{ Perempuan $(n=29)$} & \multicolumn{2}{|c|}{ Total $(n=57)$} \\
\hline & $\mathbf{n}$ & $\%$ & $\bar{n}$ & $\%$ & $\bar{n}$ & $\%$ \\
\hline Nonstunting & 14 & 50 & 8 & 27,6 & 22 & 38,6 \\
\hline
\end{tabular}




\begin{tabular}{lcccccc}
\hline Mild Stunting & 8 & 28,6 & 11 & 37,9 & 19 & 33,3 \\
Moderate Stunting & 5 & 17.9 & 8 & 27,6 & 13 & 22,8 \\
Severe Stunting & 1 & 3,6 & 2 & 6,9 & 3 & 5,3 \\
\hline
\end{tabular}

Tabel 2 menunjukkan bahwa anak perempuan lebih mudah mengalami stunting daripada anak laki-laki, dilihat dari prevalensi mild stunting, moderate stunting, dan severe stunting anak perempuan lebih tinggi daripada laki-laki.

Kadar Seng (Zn) Rambut
Nilai median kadar seng rambut pada subyek penelitian yaitu 579,13 ppm dengan kadar seng rambut terendah $182,38 \mathrm{ppm}$ dan tertinggi $2.128,8 \mathrm{ppm}$. Distribusi frekuensi kadar seng rambut pada subyek penelitian dapat dilihat pada tabel 3 .

Tabel 3. Distribusi frekuensi kadar seng rambut

\begin{tabular}{lcc}
\hline \multicolumn{1}{c}{ Kadar seng rambut (ppm) } & n & \% \\
\hline$<70$ (Defisiensi seng kronis) & 0 & 0 \\
$70-100$ (Defisiensi seng ringan) & 0 & 0 \\
$>100-500$ (Kadar seng normal) & 15 & 26,3 \\
$>500$ (Kadar seng diatas normal) & 42 & 73,7 \\
\hline Total & 57 & 100 \\
\hline
\end{tabular}

Tabel 3 menunjukkan bahwa sebagian besar subyek tergolong kadar seng rambut diatas normal yaitu 42 anak $(73,7 \%)$ dan tidak terdapat subyek

Perbedaan Kadar Seng Rambut berdasarkan Derajat Stunting yang tergolong defisiensi seng rambut.

Tabel 5. Perbedaan kadar seng rambut berdasarkan derajat stunting

\begin{tabular}{|c|c|c|c|c|}
\hline & & lar seng ram & & \\
\hline & Minimum & Maksimum & Median & p-value \\
\hline Nonstunting & 385,45 & $2.128,8$ & 644,79 & \\
\hline Mild stunting & 384,24 & 1.596 & 705,78 & \\
\hline Moderate stunting & 182,38 & $1.511,9$ & 477,14 & \\
\hline Severe stunting & 340,21 & 524,19 & 479,96 & $0,010^{*}$ \\
\hline $\begin{array}{ll}\begin{array}{l}\text { Total } \\
(n=57)\end{array} & \text { subyek } \\
\end{array}$ & 182,38 & $2.128,8$ & 579,13 & \\
\hline
\end{tabular}

Hasil penelitian menunjukkan bahwa nilai median untuk anak nonstunting (644,79 ppm) dan mild stunting $(705,78 \mathrm{ppm})$ berada pada kategori kadar seng rambut diatas normal (>500 ppm), sedangkan moderate stunting $(477,14 \mathrm{ppm})$ dan severe stunting $(475,96 \mathrm{ppm})$ berada pada kategori kadar seng rambut normal (>100-500). Berdasarkan uji
Kruskal Wallis menunjukkan bahwa terdapat perbedaan kadar seng rambut berdasarkan derajat stunting $(\mathrm{p}=0,010)$. Oleh karena itu, perlu analisis Post Hoc untuk mengetahui kelompok mana yang mempunyai perbedaan terhadap kadar seng rambut.

Tabel 6. Derajat stunting yang mempunyai perbedaan terhadap kadar seng rambut

\begin{tabular}{lc}
\hline \multicolumn{1}{c}{ Derajat stunting } & p-value $\mathbf{e}^{\mathbf{b}}$ \\
\hline Nonstunting-Mild stunting & 0,855 \\
Nonstunting-Moderate stunting & $0,010^{*}$ \\
Nonstunting-Severe stunting & $0,030^{*}$ \\
Mild stunting-Moderate stunting & $0,015^{*}$ \\
Mild stunting-Severe stunting & $0,031^{*}$ \\
\hline
\end{tabular}




\begin{tabular}{lc}
\hline Moderate stunting-Severe stunting & 0,840 \\
\hline${ }^{\mathrm{b}} \mathrm{Uji}$ Mann-Whitney ${ }^{\mathrm{p}}<0.05$ &
\end{tabular}

Pada tabel 6 menunjukkan bahwa derajat stunting yang mempunyai perbedaan kadar seng rambut yaitu nonstunting dan moderate stunting, nonstunting dan severe stunting, mild stunting dan moderate stunting, serta mild stunting dan severe stunting dengan masing-masing $\mathrm{p}$-value $<0,05$.

Uji korelasi Rank Spearman digunakan untuk mengetahui linieritas kadar seng rambut dengan z-score TB/U. Hasil uji korelasi ini menunjukkan bahwa terdapat korelasi antara kadar seng rambut dengan $\mathrm{z}$-score $\mathrm{TB} / \mathrm{U}(\mathrm{p}=0,022)$. Nilai korelasi Rank Spearman sebesar 0,303 menunjukkan terdapat korelasi positif dengan kekuatan lemah antara kadar seng rambut dengan z-score TB/U. ${ }^{13}$ Korelasi positif ini menunjukkan bahwa anak yang memiliki z-score $\mathrm{TB} / \mathrm{U}$ yang tinggi akan memiliki kadar seng rambut yang tinggi.

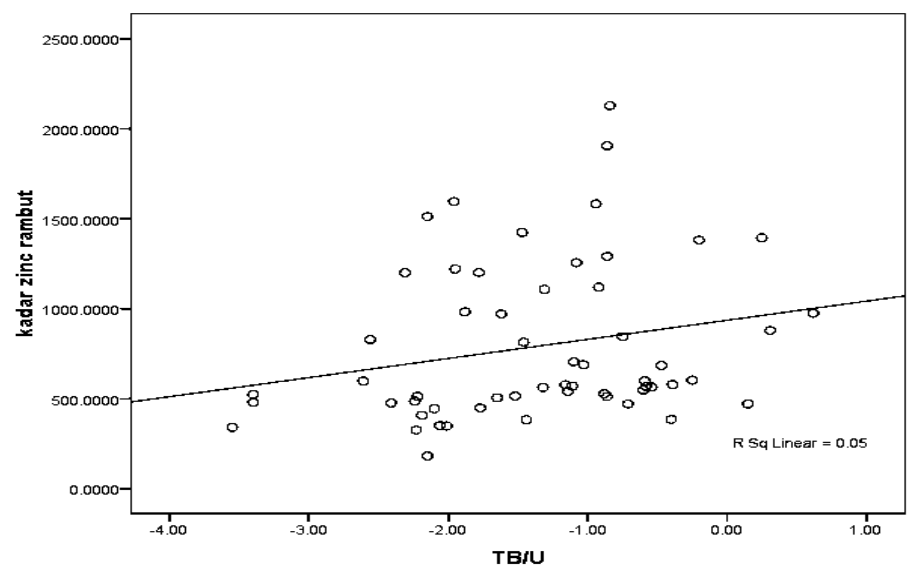

Gambar 1. Korelasi kadar seng rambut dengan z-score TB/U

\section{PEMBAHASAN \\ Derajat Stunting}

Subyek penelitian terdiri dari anak usia 6-9 tahun yang berjumlah 57 anak dari SDN 1 Purwokerto Kecamatan Patebon Kabupaten Kendal. Hasil penelitian menunjukkan bahwa rerata z-score TB/U anak laki-laki $(-1,13 \pm 0,99 \mathrm{SD})$ lebih tinggi daripada anak perempuan $(-1,58 \pm 0,79$ SD). Hasil penelitian yang dilakukan di China dengan usia subyek penelitian yang sama yaitu 6-9 tahun menunjukkan hasil yang sama yaitu z-score TB/U anak laki-laki $(-0,49 \pm 1,27)$ lebih tinggi daripada perempuan $(-0,50 \pm 1,17) .{ }^{12}$ Berdasarkan rerata $z$-score $\mathrm{TB} / \mathrm{U}$ dapat dilihat bahwa $\mathrm{z}$-score $\mathrm{TB} / \mathrm{U}$ anak laki-laki cenderung lebih tinggi daripada perempuan. Pada penelitian ini prevalensi moderate stunting anak perempuan (27,6\%) lebih tinggi daripada laki-laki $(17,9 \%)$. Hasil penelitian ini sama dengan penelitian di Iraq pada anak usia 7-12 tahun, dimana prevalensi moderate stunting anak perempuan $(19,1 \%)$ lebih tinggi daripada laki-laki (18,3\%). Perbedaan jenis kelamin dikaitkan dengan pola pertumbuhan yang berbeda, laki-laki cenderung lebih tinggi daripada perempuan. Anak perempuan cenderung stunting daripada laki-laki karena studi lain menunjukkan bahwa anak perempuan lebih sensitif terhadap lingkungan seperti penyakit infeksi, nafsu makan, dan pola asuh. ${ }^{14}$

Prevalensi stunting pada studi ini cukup tinggi, dimana prevalensi mild stunting lebih prevalen daripada moderate stunting dan severe stunting. Prevalensi mild stunting, moderate stunting, dan severe stunting berturut-turut yaitu $33,3 \%, 22,8 \%$, dan 5,3\% (Tabel 2). Prevalensi moderate stunting $(22,8 \%)$ penelitian ini lebih tinggi daripada hasil Riskesdas 2010 untuk anak sekolah dasar di Jawa Tengah, dimana prevalensi moderate stunting di Jawa Tengah sebesar 19,2\%, sementara prevalensi severe stunting (5,3\%) penelitian ini lebih rendah daripada hasil Riskesdas 2010 yaitu $14,9 \%{ }^{3}$

Stunting pada anak sekolah bervariasi di berbagai negara yang berbeda, seperti di Turkish 4,4\% anak sekolah usia 7-10 tahun mengalami stunting, sedangkan prevalensi moderate stunting anak sekolah usia 6-9 tahun di China yaitu 4,7\% dan mild stunting yaitu 22,8\% ${ }^{12,15}$ Beberapa penelitian menyatakan bahwa kejadian stunting tertinggi terjadi selama usia 2 tahun kehidupan 
pertama, dimana pada masa ini laju pertumbuhan linier mulai menurun, sementara data dari studi longitudinal menyatakan bahwa kejadian stunting berlangsung sampai usia anak sekolah. Hal ini terjadi karena laju pertumbuhan pada masa anak sekolah melambat dan kebutuhan zat gizi meningkat seiring dengan bertambahnya usia. ${ }^{16}$

Berdasarkan World Health Organization (WHO), United Nations Children's Fund (UNICEF), International Atomic Energy Agency (IAEA), dan International Zinc Nutrition Consultative Group (IZiNCG) menyatakan bahwa indikator defisiensi seng pada populasi salah satunya adalah kejadian stunting pada anak-anak dan asupan seng dibawah kebutuhan individu. Prevalensi stunting dalam populasi apabila mencapai $20 \%$ atau lebih, maka terdapat kemungkinan prevalensi defisiensi seng juga meningkat. Pada penelitian ini menunjukkan bahwa prevalensi moderate stunting $(-3 \leq \mathrm{Z}$-score $\mathrm{TB} / \mathrm{U}<-2 \mathrm{SD})$ dan severe stunting $(\mathrm{TB} / \mathrm{U}<-3 \mathrm{SD})$ berturut-turut yaitu $22,8 \%$, dan $5,3 \%$. Namun, dalam penelitian ini justru tidak ditemukan subyek yang mengalami defisiensi seng. ${ }^{17}$

\section{Kadar Seng (Zn) Rambut}

Sampai saat ini belum terdapat biomarker yang jelas untuk menunjukkan status seng secara akurat. ${ }^{12}$ Pada studi ini menggunakan seng rambut untuk menunjukkan defisiensi seng. Seng rambut menggambarkan status seng dalam jangka lama dan tidak cepat mengalami fluktuasi yang berhubungan dengan asupan makanan dan variasi diurnal. ${ }^{18}$

Rambut kepala dapat digunakan sebagai bahan biopsi untuk skrining populasi yang berisiko mengalami defisiensi trace element seperti seng. Rambut kepala menggambarkan status trace element secara kronis. ${ }^{19}$ Kadar seng rambut merupakan biomarker untuk mengetahui adanya defisiensi seng, dimana seng rambut akan diambil sebagai seng endogen untuk mencukupi kebutuhan seng. ${ }^{8,9}$

Penelitian ini menunjukkan bahwa 15 anak $(26,3 \%)$ tergolong kadar seng rambut normal, 42 anak $(73,7 \%)$ tergolong kadar seng rambut diatas normal, dan tidak ada subyek yang mengalami defisiensi seng (Tabel 3). Berdasarkan literatur yang telah ada, kadar seng rambut orang yang sehat biasanya tidak dalam batas defisiensi. Penelitian yang hampir sama juga dilakukan di Turkey pada orang sehat usia 16-20 tahun yang menunjukkan tidak terdapat subyek yang mengalami defisiensi seng, dimana rerata seng rambut subyek yaitu $216,19 \pm 16,50 \mathrm{ppm} .^{20}$
Pengukuran status seng pada tahap defisiensi seng ringan (marginal zinc deficiency) masih mengalami kesulitan karena belum terdapat indikator laboratorium yang sensitif dan akurat. Pada defisiensi seng tingkat berat, status seng tubuh dapat dilihat melalui pengukuran kadar seng rambut. Kadar seng rambut kurang sensitif untuk mengukur defisiensi seng ringan. ${ }^{21}$ Kadar seng rambut mempunyai kerugian sebagai biomonitor seperti kontaminasi (debu, keringat, kotoran rambut), warna rambut, dan perawatan rambut. Tinggi atau rendahnya kadar seng rambut memberikan gambaran kebiasaan makan dalam jangka lama, usia, dan status lingkungan (makanan, udara, air, dan tanah).$^{20}$ Seng terdapat pada udara, air, dan tanah sebagai hasil dari proses alam dan aktivitas manusia. Kadar seng rambut pada anak-anak tergantung pada tempat tinggal. ${ }^{11}$

Perbedaan Kadar Seng Rambut berdasarkan Derajat Stunting pada Anak Usia 6-9 Tahun

Pada penelitian ini didapatkan hasil bahwa nilai median kadar seng rambut pada subyek penelitian $571,13 \mathrm{ppm}$ dengan kadar seng rambut terendah $182,38 \mathrm{ppm}$ dan tertinggi $2.128,8 \mathrm{ppm}$. Hasil penelitian menunjukkan bahwa nilai median untuk moderate stunting dan severe stunting berturut-turut yaitu 477,14 ppm dan 479,96 ppm lebih rendah daripada nonstunting (644,79 ppm) dan mild stunting (705,78 ppm) (Tabel 5). Pada penelitian ini menggunakan kadar seng rambut sebagai biomarker tunggal untuk menilai status seng tubuh. Kadar seng rambut menunjukkan hasil yang stabil, tidak mudah mengalami fluktuasi, sebagian besar trace element memiliki konsentrasi tinggi pada rambut daripada bagian tubuh lainnya. Rendahnya kadar seng rambut pada anak menjadi indikator rendahnya status seng dalam tubuh, tetapi kadar seng rambut normal atau diatas normal seperti pada penelitian ini belum dapat sepenuhnya menggambarkan status seng tubuh. Status seng dalam tubuh akan lebih jelas ketika diukur 2 biomarker yaitu kadar seng rambut dan kadar seng serum. $^{22}$

Berdasarkan analisis bivariat Kruskal Wallis menunjukkan bahwa terdapat perbedaan yang bermakna secara statistik antara kadar seng rambut dengan derajat stunting $(\mathrm{p}=0,010)$. Derajat stunting yang mempunyai perbedaan kadar seng rambut yaitu nonstunting dan moderate stunting, nonstunting dan severe stunting, mild stunting dan moderate stunting, serta mild stunting dan severe stunting dengan masing-masing p-value $<0,05$. Uji korelasi Rank Spearman menunjukkan bahwa terdapat korelasi antara kadar seng rambut dengan 
status gizi anak berdasarkan z-score TB/U $(\mathrm{p}=0,022 ; \mathrm{r}=0,303)$, hasil tersebut juga menunjukkan korelasi positif dimana anak yang memiliki z-score $\mathrm{TB} / \mathrm{U}$ yang rendah akan cenderung memiliki kadar seng rambut yang rendah.

\section{KETERBATASAN PENELITIAN}

Penelitian ini memiliki keterbatasan dalam pelaksanaannya, yaitu tidak diteliti mengenai faktor lingkungan, penyakit infeksi maupun sosial ekonomi keluarga yang juga mempengaruhi kadar seng rambut dan derajat stunting.

\section{SIMPULAN}

1. Jumlah subyek dalam penelitian ini yaitu 57 anak, dimana anak yang nonstunting sebanyak $38,6 \%$, mild stunting sebanyak 33,3\%, moderate stunting sebanyak $22,8 \%$, dan severe stunting sebanyak 5,3\%.

2. Sebanyak 15 subyek $(26,3 \%)$ tergolong kadar seng rambut normal, 42 subyek $(73,7 \%)$ tergolong kadar seng rambut diatas normal, dan tidak ada subyek yang mengalami defisiensi seng.

3. Terdapat perbedaan yang bermakna antara kadar seng rambut dengan derajat stunting $(\mathrm{p}=0,010)$. Derajat stunting yang mempunyai perbedaan kadar seng rambut yaitu nonstunting dan moderate stunting, nonstunting dan severe stunting, mild stunting dan moderate stunting, serta mild stunting dan severe stunting. Kadar seng rambut akan meningkat dengan meningkatnya $\mathrm{z}$-score TB/U. Berdasarkan uji statistik, terdapat korelasi antara kadar seng rambut dengan status gizi anak berdasarkan $\mathrm{z}$-score $\mathrm{TB} / \mathrm{U}$ $(\mathrm{r}=0,303 ; \mathrm{p}=0,022)$.

\section{SARAN}

1. Perlu dilakukan penelitian dengan melihat kadar seng rambut pada anak dengan status gizi buruk, karena kadar seng rambut lebih sensitif untuk menggambarkan anak dengan defisiensi seng kronik.

2. Perlu dilakukan penelitian mengenai faktor yang mempengaruhi kadar seng rambut, seperti kondisi lingkungan (udara, tanah, air) dan penyakit infeksi.

3. Perlu penelitian lebih lanjut mengenai kadar seng rambut dengan derajat stunting dengan metode lain seperti case-control untuk meminimalkan variabel luar yang ikut berpengaruh serta jumlah sampel yang lebih banyak.

\section{DAFTAR PUSTAKA}

1. Ramli, Agho KE, Inder KJ, Bowe SJ, Jacobs J, Dibley MJ. Prevalence and risk factors for stunting and severe stunting among under-fives in North Maluku province of Indonesia. BMC Pediatrics 2009.

2. Arisman. Gizi dalam daur kehidupan : buku ajar ilmu gizi. Jakarta : Buku Kedokteran EGC;2004: p.63.

3. Departemen Kesehatan Republik Indonesia. Riset Kesehatan Dasar 2010. Badan Penelitian dan Pengembangan Kesehatan. 2010.

4. Gallagher ML. The Nutrient and Their Metabolism. In : Mahan LK, Escott-Stump S, editors. Krause's Food \& Nutrition Therapy. 12nd edition. Canada : Saunders an imprint of Elsevier Inc. 2008: 121

5. Fesharakinia A, Zarban A, Sharifzadeh GR. Prevalence of zinc deficiency in Elementary School Children of South Khorasan Province (East Iran). Iranian Journal of Pediatrics 2009;19(3): 249-54.

6. Adhi KT, Wirjatmadi B, Adriani M. Perbedaan kadar seng serum dan kadar c-reactive protein pada anak balita dengan kadar serum retinol normal dan tidak normal. Jurnal Gizi Klinik Indonesia 2010 Nov; 7(2): 58-63.

7. Takyi EE. Hair zinc status and its correlation with height indicator in pre-school and school children from a mixed income, low density (mild) community in Southern Ghana. East African Medical Journal 2004 Jan;81(1):42-6.

8. Lowe NM, Fekete K, Decsi T. Methods of assessment of zinc status in humans: a systematic review. Am J Clin Nutr 2009;89(suppl):2040S$51 \mathrm{~S}$.

9. Huwae FJ. Hubungan antara kadar seng ( $\mathrm{Zn}$ ) dengan memori jangka pendek pada anak sekolah dasar. [Tesis]. Semarang : Universitas Diponegoro. 2006.

10. Data Penjaringan Anak Sekolah 2011. Puskesmas Patebon dan Kota Kendal di Kabupaten Kendal.

11. Trojanowski Piotr, Trojanowski Jan, Bokiniec M, Antonowicz J, Trojanowska Czeslawa. Zinc in hair of the Middle Pomerania Human Population (Poland). Institute of Biology and Environmental Protection Pomeranian University. (13). 2009 : 4965.

12. Qin $\mathrm{Y}$, Melse-Boonstra A, Zhao J, Wu M, Hu X, Kok JF. Stunting and zinc deficiency among primary school children in rural areas with low soil zinc concentrations in Jiangsu Province, China. Asia Pac J Clin Nutr 2009; 18(1) : 15-21.

13. Dahlan MS. Statistik untuk Kedokteran dan Kesehatan. Edisi 4. Jakarta : Salemba Medika.2009; 157. 
14. Al-Saffar AJ. Stunting among primary-school children : a sample from Baghdad, Iraq. Eastern Mediterranean Health Journal 2009; 15(2):322-9.

15. Gur E, Can G, Akkus S, Ercan G, Arvas A, Guzeloz S, Cifcili S. Is undernutrition a problem among Turkish school children?: Which factors have an influence on it? Journal of Tropical Pediatrics. 2006;52:421-6.

16. Friedman JF, Phillips-Howard PA, Mirel LB, Terlouw DJ, Okello N, Vulule JM, Hawley WA, Nahlen BL, ter Kuile F. Progression of stunting and its predictors among school-aged children in western Kenya. European Journal of Clinical Nutrition (2005) 59, 914-922.

17. de Benoist B, Darnton-Hill I, Davidsson L, Fontaine O, Hotz C. Conclusions of the Joint WHO/UNICEF/IAEA/IZiNCG Interagency Meeting on Zinc Status Indicators. Food Nutr Bull. 2007 Sep;28(3 Suppl):S480-4.

18. Hambidge M. Biomarker of trace mineral intake and status. Journal of Nutrition 2003; 133 Suppl 3:948S-55S.

19. Gibson RS. Principles of Nutritional Assessment. Second edition. Oxford University Press. 2005. p.380.

20. Yasar U, Ozyigit. Use of Human as a Potential Biomonitor for Zinc in the Pendik District Istanbul Turkey. Roumanian Society of Biological Sciences. 2009;14(3):4477-84.

21. Wood RJ. Assessment of Marginal Zinc Status in Humans. Journal of Nutrition. 2000;130:1350S-4S.

22. Kurtoglu S, Kokla E, Hatipoglu N, Atabek ME. The relationship between serum ghrelin levels and hair zinc concentrations in children. Journal of Turkish Pediatric Endocrinology and Diabetes Society. 2008;1(1):1-7. 